\section{Growth potential of Listeria monocytogenes in six different RTE fruit products: impact of food matrix, storage tempera- ture and shelf life}

\author{
Matthias Ziegler, ${ }^{1}$ Simon Rüegg, ${ }^{2}$ \\ Roger Stephan, ${ }^{1}$ Claudia Guldimann ${ }^{1}$ \\ ${ }^{1}$ Institute for Food Safety and Hygiene, \\ and ${ }^{2}$ Section of Epidemiology, Vetsuisse \\ Faculty, University of Zürich, \\ Switzerland
}

\begin{abstract}
We tested the growth potential of Listeria monocytogenes on six RTE fruit products at low $\left(4^{\circ} \mathrm{C}\right.$ at the factory followed by $8^{\circ} \mathrm{C}$ retail/home storage) and abusive $\left(4^{\circ} \mathrm{C}\right.$ followed by $\left.12^{\circ} \mathrm{C}\right)$ storage temperatures. Sliced coconut and fresh cut cantaloupe, as well as a fruit mix containing diced pineapple, cantaloupe, apples and grapes supported the growth of $L$. monocytogenes with a growth potential $\delta>0.5 \log$ $\mathrm{CFU} / \mathrm{g}$ over six days. Mangoes, a mix of diced kiwi, cantaloupe and pineapple as well as a mix of diced pineapple, mango, grapefruit, kiwi and pomegranate did not support a growth potential that exceeded 0.5 $\log \mathrm{CFU} / \mathrm{g}$ over six days. The growth potential of L. monocytogenes correlated significantly with the $\mathrm{pH}$; no product with a $\mathrm{pH}$ below 4 showed a significant growth potential of L. monocytogenes. Time after inoculation was also a significant predictor of the growth potential, while the fruit type and storage temperature were not.
\end{abstract}

\section{Introduction}

Lifestyle choices and the demand for healthier food in its natural state result in an upwards trend in sale of minimally processed raw fruit or vegetables products (EFSA, 2017). These products do not typically undergo any processing step intended to kill pathogens and are consumed as ready to eat (RTE) products. This raises a significant challenge to food safety, and various outbreaks due to food borne pathogens on ready to eat fruit and vegetable products have been reported. Typical examples are outbreaks with E. coli O157:H7 (Sharapov et al., 2016), Salmonella (Sivapalasingam et al., 2003; Beatty et al., 2004; FDA, 2014; Vestrheim et al., 2016), L. monocytogenes (McCollum et al., 2013; Chen et al., 2016) and norovirus (Harris et al., 2003; Bassett and McClure, 2008; Hall et al., 2012). A British study in 2016 found that
$5.4 \%$ of RTE precut fruit products were contaminated with L. monocytogenes and other Listeria species (Willis et al., 2016). The process of cutting fruit pieces as well as the mixing of different fruits are assumed to increase the risk of contamination with $L$. monocytogenes at the production stage. A measure for the potential risk posed to consumers by L. monocytogenes in a certain product is the growth potential $\delta$, defined as the difference between the $\log _{10} \mathrm{CFU} / \mathrm{g}$ at the beginning and end of the products shelf life (Beaufort et al., 2014). $\delta$ depends on the physical properties of the product, the storage temperature and the shelf life. To adequately assess the risk associated with raw RTE products and to take effective preventive measures, it is therefore crucial to determine the growth potential of L. monocytogenes on the food matrix under storage conditions that reflect the production, retail and consumer home environment. The risk of contamination of food and subsequent human infection with Listeria monocytogenes is exacerbated by its frequent presence in the environment and growth potential at refrigeration temperatures (Chan and Wiedmann, 2009). In this context, temperature conditions in challenge studies should account for the fact that while production facilities tend to have closely monitored temperature management systems, refrigerated display cases at the retail level and home refrigerators are often found at abusive temperatures (James et al., 2016; Jouhara et al., 2017).

We have recently published data on the growth potential of $L$. monocytogenes on different RTE salad products (Ziegler et al., submitted). Apart from salads, several outbreaks of listeriosis in the past were linked to fruit; examples are stone fruit (Chen et al., 2016), caramel apples (Angelo et al., 2017), and cantaloupe (McCollum et al., 2013). The aim of the present study was to determine the growth potential of L. monocytogenes on RTE fruit products. All products included in this study were precut fruit, with both mono-products as well as mixed fruit products represented. Since some fruits and vegetables produce antimicrobials that are active against $L$. monocytogenes (Beuchat and Brackett, 1990; Cvetnić and Vladimir-Knezević, 2004; Babic et al., 2008; Hayrapetyan et al., 2012), a relatively high inoculum was used to allow accurate measurements of growth of L. monocytogenes as well as antimicrobial plant effects.

\section{Materials and Methods}

All experiments were carried out in three independent replicates.
Correspondence: Claudia Guldimann, Institute for Food Safety and Hygiene, Vetsuisse Faculty, University of Zürich, Winterthurerstr. 272, 8057 Zürich, Switzerland.

Tel.: +41.44.6358680.

E-mail: claudia.guldimann@uzh.ch

Key words: Challenge study, Total viable count, Mango, Cantaloupe, Coconut.

Acknowledgements: We thank Denise Althaus for serotyping of the L. monocytogenes strains published here.

Conflict of interest: The authors declare no potential conflict of interest.

Funding: This work was supported by the University of Zurich.

Received for publication: 29 May 2018.

Revision received: 30 August 2018.

Accepted for publication: 5 September 2018.

This work is licensed under a Creative Commons Attribution-NonCommercial 4.0 International License (CC BY-NC 4.0).

(C) Copyright M. Ziegler et al., 2018

Licensee PAGEPress, Italy

Italian Journal of Food Safety 2018; 7:7581

doi:10.4081/ijfs.2018.7581

\section{Bacterial strains, growth conditions} and subtyping

The three strains of $L$. monocytogenes used in this study were all isolated from an RTE salads or RTE fruit mixes (Table 1). The growth properties of strain N16-0716 have been previously characterized (Ziegler et al., submitted) and its genome was published (Ziegler et al., 2018). Strains N162670 and N16-1278 were isolated from a RTE fruit production plant and are therefore inherently likely to be found on RTE fruit products. Stock cultures of L. monocytogenes were maintained at $-80^{\circ} \mathrm{C}$ in brain heart infusion (BHI; Oxoid, Basel, Switzerland) broth with $15 \%$ glycerol. To prepare the inocula, stock cultures were streaked on BHI agar plates and incubated overnight. A single colony was inoculated into $5 \mathrm{~mL}$ BHI broth and incubated overnight $\left(37^{\circ} \mathrm{C}, 200 \mathrm{rpm}\right)$, subcultured in the morning 1:100 into $5 \mathrm{~mL}$ fresh BHI broth, and incubated for $6 \mathrm{~h}\left(37^{\circ} \mathrm{C}, 200\right.$ $\mathrm{rpm})$ to obtain an early-stationary-phase culture $(9.5 \pm 0.8 \log \mathrm{CFU} / \mathrm{mL})$. This culture was then incubated at $5^{\circ} \mathrm{C}$ for $20 \mathrm{~h}$ to simulate the storage conditions L. monocytogenes would undergo during the production of RTE fruit products at room temperature followed by cold storage. Strain pools were obtained by combining equal quantities of the cold adapted stationary phase cultures. 


\section{Fruit products}

The six different RTE fruit products were obtained from a manufacturer who produced $30 \mathrm{~g}$ portions specifically for this study (Table 2). This small unit size was chosen to allow processing of the total content of each package for microbial analysis, thus avoiding sampling bias. The fruit pieces contained within each package were identical in size and shape to the pieces contained in the larger packaging units destined for retail; the edges of the fruit cubes were approximately $1-2 \mathrm{~cm}$ long. The products were shipped to the lab under preservation of the cold chain at $5^{\circ} \mathrm{C}$ and inoculated 12 $24 \mathrm{~h}$ after production. The packaging was identical to the larger packages that were produced for retail, and the products were packaged in the same production line as the commercially sold products. None of the products were packaged under modified atmosphere. To achieve three independent replicates, products from three different lot numbers were shipped to our facility on three different days.

\section{Inoculation of the RTE fruit products}

Maximum Recovery Diluent (MRD; Oxoid, Basel, Switzerland) was chosen as a diluent for the inoculum as well as for the serial dilutions for colony counting because it is recommended in ISO6887-1 to achieve maximal recovery of microbes, while the low peptone concentration of $1 \%$ prevents immediate multiplication of microorganisms to allow for an accurate enumeration. To achieve a final bacterial load of $4 \mathrm{log}$ $\mathrm{CFU} / \mathrm{g}$ in the products, the cold adapted stationary phase culture was serially diluted in $10 \mathrm{~mL} \mathrm{MRD}$, and $1 \mathrm{~mL}$ of the appropriate dilution was homogeneously distributed over the product. This relatively high concentration was chosen to be able to accurately quantify not only an increase, but also a decrease in CFU/g. The inoculum was administered through a septum of scotch tape using a syringe and a gauge 22 needle. Immediately after inoculation, the syringe hole was sealed with a second scotch tape to maintain the integrity of the packaging. Negative control samples were inoculated in the same way with $1 \mathrm{~mL}$ MRD. After inoculation, all samples were shaken for 1 min in a standardized manner to optimize the distribution of the inocula. This shaking had no visible effect on the size or integrity of the fruit pieces. To preserve the cold chain, the packaged fruit and the bacteria were kept on ice during all procedures.

\section{Storage conditions}

The products were stored at two different storage conditions for 3, 4, 5 and 6 days. Storage condition 1 mimics compliance with reasonable storage temperatures $\left(4^{\circ} \mathrm{C}\right.$ at the factory, $8^{\circ} \mathrm{C}$ at retail/at the consumer), while the storage condition 2 mimics abusive temperatures $\left(4^{\circ} \mathrm{C}\right.$ at the factory, $12^{\circ} \mathrm{C}$

Table 1. Bacterial strains.

\begin{tabular}{llccccc} 
Bacteria & \multicolumn{1}{c}{$\begin{array}{c}\text { Source } \\
\text { Listeria monocytogenes }\end{array}$} & $\begin{array}{c}\text { Serotype } \\
\text { Fruit production company }\end{array}$ & $\begin{array}{c}\text { Sequence } \\
\text { type }\end{array}$ & Clonal & $\begin{array}{c}\text { Complex } \\
\text { lineage }\end{array}$ & $\begin{array}{c}\text { Internal } \\
\text { identification number }\end{array}$ \\
Listeria monocytogenes & Salad production company & $1 / 2 \mathrm{~b}$ & ST403 & CC403 & II & N17-2670 \\
\hline Listeria monocytogenes & Fruit production company & 4b & ST388 & CC388 & I & N16-0716 \\
\hline
\end{tabular}

\begin{tabular}{|c|c|c|c|c|c|c|}
\hline $\begin{array}{l}\text { RTE } \\
\text { product }\end{array}$ & Ingredients & Additives & $\mathrm{pH}$ & Contrast* & $\begin{array}{l}\text { Challenge test } \\
\qquad 4 \mathrm{C}+8 \mathrm{C} \\
\text { Growth potential }^{* *}\end{array}$ & $\begin{array}{l}\text { results summary } \\
\qquad 4 \mathrm{C}+12 \mathrm{C} \\
\text { Growth potential** }\end{array}$ \\
\hline Fruit mix 1 & $\begin{array}{l}\text { Mix of diced pineapple (50.1\%), mango (17.6\%), } \\
\text { grapefruit (17.6\%), } \\
\text { kiwi (11.8\%) and pomegranate (2.9\%) } \\
\text { Ananas comosus, Mangifera indica, } \\
\text { Citrus paradisi, Cucumis melo, Punica granatum }\end{array}$ & $\begin{array}{l}\text { E302, E330 } \\
\text { (mango) }\end{array}$ & 3.4 & $\begin{array}{l}0-3 \\
0-4 \\
0-5 \\
0-6\end{array}$ & $\begin{array}{l}0.06 \\
0.11 \\
0.14 \\
0.10\end{array}$ & $\begin{array}{l}0.10 \\
0.09 \\
0.04 \\
0.18\end{array}$ \\
\hline Fruit mix 2 & $\begin{array}{l}\text { Mix of diced pineapple }(36.6 \%) \text {, } \\
\text { cantaloupe }(26.7 \%) \text {, apple }(26.6 \%) \\
\text { and grapes }(10 \%) \\
\text { Ananas comosus, Cucumis melo, } \\
\text { Malus domestica, Vitis vinifera }\end{array}$ & $\begin{array}{l}\text { E302, E330 } \\
\text { (apple) }\end{array}$ & 4.2 & $\begin{array}{l}0-3 \\
0-4 \\
0-5 \\
0-6\end{array}$ & $\begin{array}{l}0.14 \\
0.40 \\
0.52 \\
0.92\end{array}$ & $\begin{array}{l}0-15 \\
0.95 \\
1.03 \\
1.07\end{array}$ \\
\hline Cantaloupe & $\begin{array}{l}\text { Cantaloupe (diced) 100\% } \\
\text { Cucumis melo }\end{array}$ & $\mathrm{n} / \mathrm{a}$ & 5.6 & $\begin{array}{l}0-3 \\
0-4 \\
0-5 \\
0-6\end{array}$ & $\begin{array}{l}1.23 \\
2.04 \\
2.65 \\
2.56\end{array}$ & $\begin{array}{l}1.29 \\
2.73 \\
2.79 \\
2.60\end{array}$ \\
\hline Fruit mix 3 & $\begin{array}{l}\text { Mix of diced kiwi (20\%), cantaloupe (50\%) } \\
\text { and pineapple ( } 30 \%) \\
\text { Actinidia deliciosa, Cucumis melo, Ananas comosus }\end{array}$ & $\mathrm{n} / \mathrm{a}$ & 3.9 & $\begin{array}{l}0-3 \\
0-4 \\
0-5 \\
0-6\end{array}$ & $\begin{array}{l}0.19 \\
0.15 \\
0.15 \\
0.16\end{array}$ & $\begin{array}{l}0.12 \\
0.21 \\
0.46 \\
0.42\end{array}$ \\
\hline Coconut & $\begin{array}{l}\text { Diced coconut pieces } 100 \% \\
\text { Cocus nucifera }\end{array}$ & $\mathrm{n} / \mathrm{a}$ & 6.4 & $\begin{array}{l}0-3 \\
0-4 \\
0-5 \\
0-6\end{array}$ & $\begin{array}{l}1.26 \\
3.00 \\
3.04 \\
3.63\end{array}$ & $\begin{array}{l}1.39 \\
2.69 \\
4.19 \\
4.80\end{array}$ \\
\hline Mango & $\begin{array}{l}\text { Peeled, diced mango pieces (100\%) } \\
\text { Mangifera indica }\end{array}$ & 02, E330 (mango) & 3.6 & $\begin{array}{l}0-3 \\
0-4 \\
0-5 \\
0-6\end{array}$ & $\begin{array}{c}0.14 \\
0.11 \\
0 \\
0.13\end{array}$ & $\begin{array}{l}0.08 \\
0.09 \\
0.01 \\
0.03\end{array}$ \\
\hline
\end{tabular}


at retail/at the consumer and an additional $2 \mathrm{~h}$ of sitting without cooling prior to consumption). Therefore, storage condition 1 comprised storage at $4^{\circ} \mathrm{C}$ for $72 \mathrm{~h}$, then at $8^{\circ} \mathrm{C}$ for the remainder of the protocol. Storage condition 2 comprised storage at 4 $\mathrm{C}$ for $72 \mathrm{~h}$, then at $12^{\circ} \mathrm{C}$. Prior to processing the condition 2 samples, they were kept at $20^{\circ} \mathrm{C}$ for $2 \mathrm{~h}$. Temperature in all cold storage facilities was continuously controlled and recorded with temperature loggers (EasyLog, Lascar Electronics, Pennsylvania, USA).

\section{Microbiological analyses}

L. monocytogenes and total viable count (TVC) were determined immediately after inoculation $(\mathrm{t}=0)$ and $3,4,5$ and 6 days after inoculation. At each time point, one inoculated sample and one negative (uninoculated) control sample per temperature were analyzed, representing one replicate. The whole content of a unit was transferred into sterile stomacher bags, diluted 1:5 with MRD and homogenized for $30 \mathrm{~s}$ in a Stomacher® 400 Circulator (Seward, Worthing, United Kingdom). Serial dilutions in MRD were prepared and $0.1 \mathrm{~mL}$ was spread-plated on the following agar plates in duplicate: PALCAM (Merck, Darmstadt, Germany) for the enumeration of L. monocytogenes and Plate Count Agar (PC; Oxoid, Basel, Switzerland) for TVC. While the low $\mathrm{pH}$ of the fruit may have negatively influenced the recovery of stressed cells on PALCAM agar, the dilution steps in MRD would mitigate most of this effect. The average of the duplicate plates was calculated and expressed as $\log \mathrm{CFU} / \mathrm{g}$. The limit of detection was $2 \log \mathrm{CFU} / \mathrm{g}$. The $\mathrm{pH}$ of the negative control samples was determined at each time point using an Orion Versa Star $\mathrm{pH}$ meter (Thermo Fisher, Switzerland) equipped with a solid matter probe. In products containing only one type of fruit, two individual pieces of fruit and the accumulating juice in the container were measured. For products comprised of more than one type of fruit, the $\mathrm{pH}$ of all individual constituents of the product and the accumulating juice were measured. Since it was impossible to determine on which pieces of fruit bacteria grew to what extent, the average $\mathrm{pH}$ was calculated as the mean from these values to approximate the overall acidity of the product. The pieces of coconut in our samples were too small to allow accurate $\mathrm{pH}$ measurement and we therefore used the mean of 6.4 from different published values (Sinigaglia et al., 2006a). The $\mathrm{pH}$ of pomegranade seeds was not measured due to their small size.

\section{Calculation of the growth potential $\delta$}

For each time point at each temperature, the difference between the $\log \mathrm{CFU} / \mathrm{g}$ at the evaluation point and the $\log \mathrm{CFU} / \mathrm{g}$ at the beginning of the challenge test was calculated for each of the three independent replicates. The growth potential $\delta$ was defined as the highest value obtained among three replicates. When $\delta$ was higher than $0.5 \log \mathrm{CFU} / \mathrm{g}$ the RTE fruit product was classified as able to support the growth of L. monocytogenes at the corresponding temperature. If $\delta$ was $\leq 0.5 \log \mathrm{CFU} / \mathrm{g}$ the RTE fruit product was classified as unable to support the growth of L. monocytogenes.

\section{Statistical analysis}

Statistical analysis and graphics were performed in R (Version 3.4.0) using R studio (Version 1.0.143) (RStudio Team 2015). Generalized linear models without interactions were fitted (glm in $\mathrm{R}$ stats package version 3.4.2) to model the growth potential of L. monocytogenes and the log CFU TVC in each fruit product as a function of product, temperature, $\mathrm{pH}$ and time. The ggplot2 package (Wickham, 2009) was used for visualization. Please see online Appendix for R scripts.

\section{Results}

\section{Growth potential of $L$. monocyto- genes on RTE fruit products}

We measured the growth potential for each RTE fruit product at $\mathrm{t}=3,4,5$ and 6 days (Table 2). Any products that show a growth potential $\delta>0.5 \log$ CFU are considered permissive to the growth of L. monocytogenes under EU regulations (Beaufort et al., 2014). Among the products tested here,

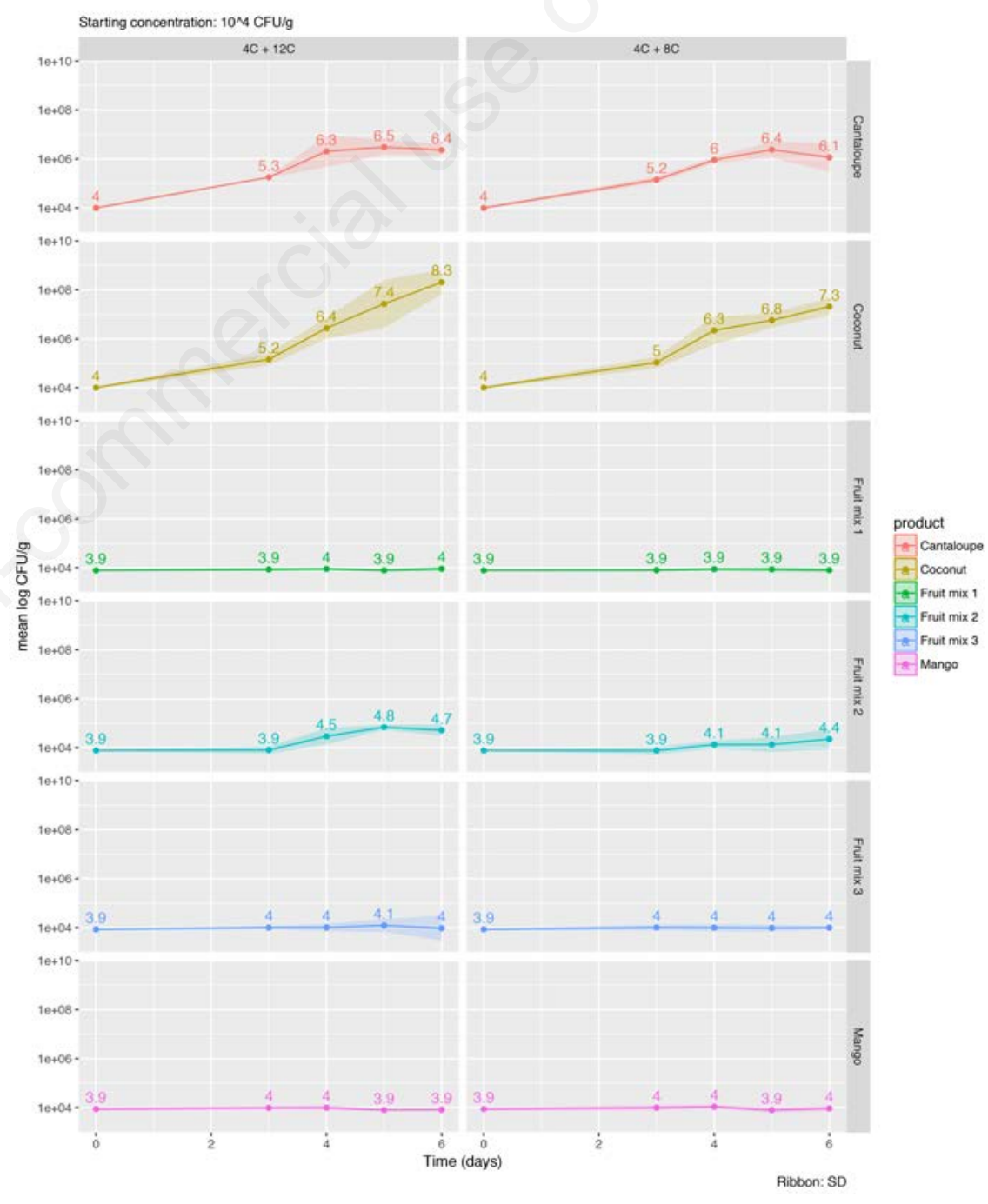

Figure 1. CFU count of Listeria monocytogenes on salad. Growth curves of L. monocytogenes on RTE fruit products. The numbers above the lines represent the mean CFU/g at this time point, the ribbon around the line the SD of each value. 
the highest growth potential was observed in RTE coconut after 8 days at the abusive storage condition $2 . \delta$ exceeded $0.5 \mathrm{log}$ $\mathrm{CFU}$ at most time points and under both storage conditions in coconut, fruit salad 2 and cantaloupe. The lowest growth potential trending towards zero was observed in mango. In mango, fruit mix 1 and fruit mix $3 \delta$ was $<0.5 \log$ CFU at all time points at both storage conditions (Table 2).

\section{Impact of the $\mathrm{pH}$ and fruit product on the growth potential of L. mono- cytogenes}

$\mathrm{pH}$ had a significant impact on the growth potential of L. monocytogenes ( $\mathrm{p}<$ $0.001)$, while the fruit type did not ( $\mathrm{p}=$ 0.86 ). A significant growth potential for $L$. monocytogenes was only observed in products with relatively high $\mathrm{pH}$ : coconut, cantaloupe and fruit mix 2 (Table 2). The highest number of L. monocytogenes after six days was observed in coconut stored under condition $2(\delta=4.8$, resulting in 8.3 $(\mathrm{SD}=0.5) \log \mathrm{CFU} / \mathrm{g})$ (Figure 1, Table 2).

In fruit mix 1, fruit mix 3 and mango, the $\mathrm{pH}$ was lower (Table 2) and the growth potential of L. monocytogenes did not exceed $0.5 \log$ CFU over the whole experimental period. The lowest number of $L$. monocytogenes after six day was observed in mango stored under condition $2(\delta=$ 0.03 , resulting in $3.9(\mathrm{SD}=0.04) \log \mathrm{CFU} / \mathrm{g})$ (Figure 1, Table 2).

\section{Impact of time on the growth poten- tial of $L$. monocytogenes}

Not surprisingly, time had a significant impact on the growth potential of L. monocytogenes on fruit products $(\mathrm{P}<0.001)$. Where the product was permissive for the growth of L. monocytogenes, the growth potential was higher at later time points compared to earlier time points, which is also reflected in the $\log \mathrm{CFU} / \mathrm{g}$ over time (Figure 1).

\section{Impact of temperature on the growth potential of $L$. monocyto- genes}

The storage temperatures were chosen to reflect likely scenarios during the shelf life of RTE fruit products. Correct storage at $4^{\circ} \mathrm{C}$ at the production facility was assumed for both temperature regimens, followed by either correct (condition $1,8^{\circ} \mathrm{C}$ ) or abusive (condition $2,12^{\circ} \mathrm{C}$ ) storage during retail/at home. The two different storage conditions did not have a significant impact on the growth potential in this study $(\mathrm{P}=0.36)$. Accordingly, in products that did not permit the growth of L. monocytogenes, we observed steady numbers of $\log \mathrm{CFU} / \mathrm{g}$ under both temperature regimens.

However, where the product permitted the growth of L. monocytogenes, a trend towards higher numbers of $\mathrm{CFU} / \mathrm{g}$ was observed in samples stored under condition 2 compared to condition 1 (Figure 1). For example, in coconut at $\mathrm{t}=6$ we observed 7.3 $(\mathrm{SD}=0.34) \log \mathrm{CFU} / \mathrm{g}$ under storage condition 1 which follows regulations vs 8.3 $(\mathrm{SD}=0.5) \log \mathrm{CFU} / \mathrm{g}$ under the abusive storage condition 2. Given the overlap of the SD these differences were not statistically significant.

\section{Total viable count on RTE fruit products}

All fruit products had initial TVC counts around $4 \log \mathrm{CFU} / \mathrm{g}$ (Figure 2). The highest final TVC count was $8.8(\mathrm{SD}=0.5)$ $\log \mathrm{CFU} / \mathrm{g}$ in coconut stored under condition 2. The lowest final TVC count was 5 $\log \mathrm{CFU} / \mathrm{g}(\mathrm{SD}=0.7)$ in fruit mix 3 stored under condition 1 .

For the TVC, time and storage temperature had significant impact on the outcome $\mathrm{CFU} / \mathrm{g}$, while $\mathrm{pH}$ did not. Fruit mix 3 supported significantly less growth compared to the other fruit products.

\section{Discussion and Conclusions}

The $\mathrm{pH}$ of the RTE fruit products was a significant determinant of the L. monocytogenes growth potential, while it did not significantly influence the TVC counts. This may be explained by the fact that the TVC counts reflect a large number of species, some of them adapted to the specific fruit

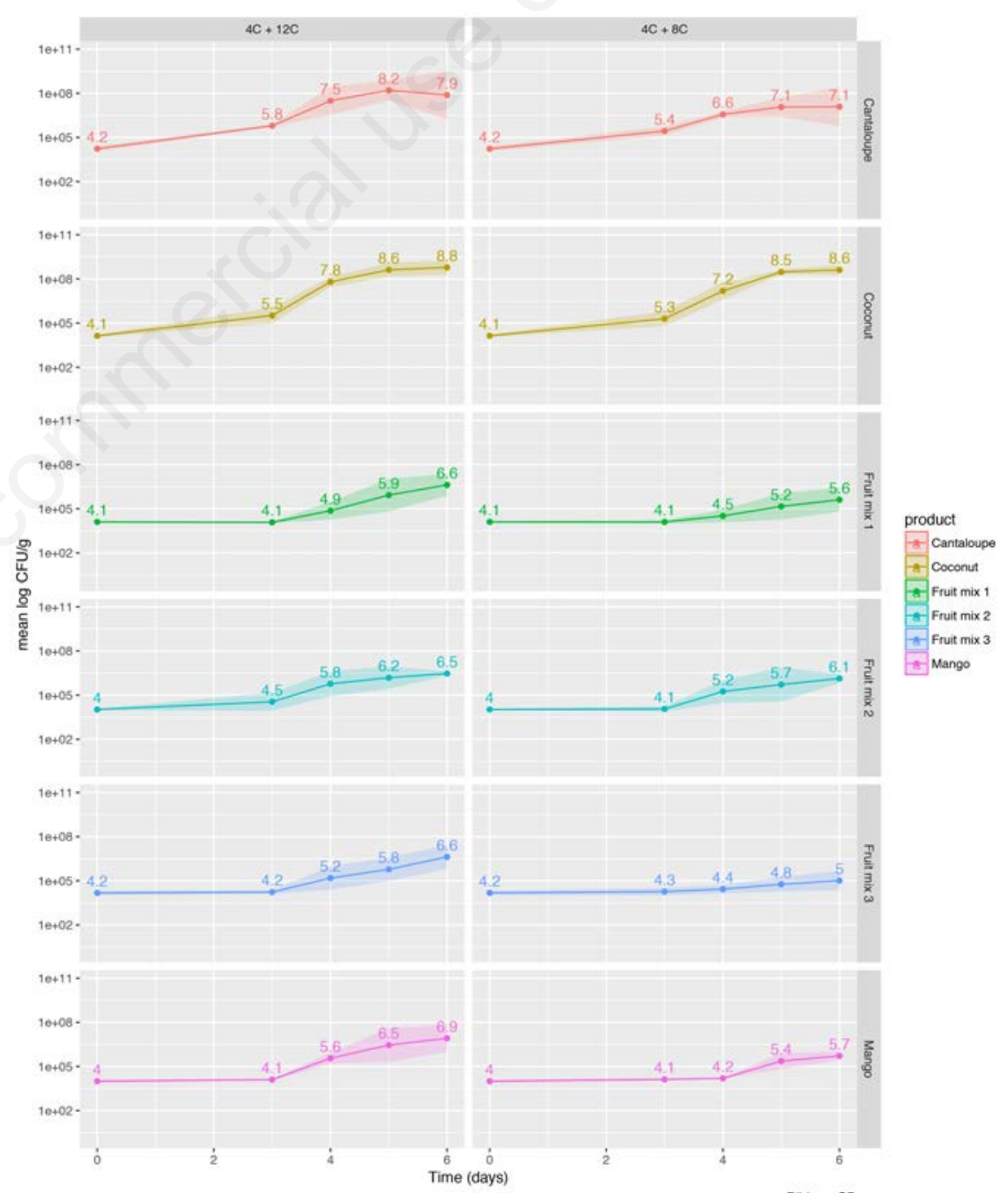

Figure 2. Mean CFU for the Total Viable Count in the inoculated samples. Growth curves of total viable counts on RTE fruit products. The numbers above the lines represent the mean CFU/g at this time point, the ribbon around the line the SD of each value. 
they were isolated from. In contrast, $L$. monocytogenes can survive a $\mathrm{pH}$ as low as 2.5 for two hours but growth is impaired with sinking $\mathrm{pH}$ and absent below $\mathrm{pH} 4.0$ (Smith et al., 2013). EU regulations assume no growth potential for $L$. monocytogenes in products with a $\mathrm{pH}$ below 4.4, (Codex Alimentarius, EC Regulation No 2073/2005). The fruit type did not significantly influence the growth potential. While there is an obvious connection between fruit type and $\mathrm{pH}$, fruit from different lots may vary in acidity depending on their ripeness, and in fruit mixtures the $\mathrm{pH}$ of individual pieces of fruit may be influenced by the mixture as a whole. Our $\mathrm{pH}$ measurements for one fruit type over different experiments had standard deviations in the range of $\mathrm{pH}$ 0.1-0.6, which offers an explanation why $\mathrm{pH}$ was a more accurate predictor of the growth potential compared to fruit type.

Among the single ingredient products included in this study, mangoes did not support the growth of L. monocytogenes. A study analyzing the growth of L. monocytogenes on fresh cut mango slices also found no growth at $3 \pm 2{ }^{\circ} \mathrm{C}$ (Rangel-Vargas et al., 2018). This is contrary to other authors who found a significant increase of L. monocytogenes on fresh cut mango pieces over time: a $4 \log$ CFU increase of $L$. monocytogenes Scott A was observed after $200 \mathrm{~h}$ at $10^{\circ} \mathrm{C}$ in sterilized mango pulp (Penteado et al., 2014). Potential explanations for this discrepancy are the missing plant microbiota and the higher $\mathrm{pH}$ (5.16) of the mango pulp used by these authors compared to the mango pieces in our study with an average $\mathrm{pH}$ of 3.9. In another study, the inoculation of fresh cut mango cubes ( $\mathrm{pH} 4.2$ ) with a mixture of six strains of $L$. monocytogenes resulted in 2 and $5.4 \log$ CFU increases over 6 days at $5^{\circ} \mathrm{C}$ and $13^{\circ} \mathrm{C}$, respectively (Feng et al., 2015).

We observed significant growth of $L$. monocytogenes on cantaloupe and coconut pieces, which represent the two low-acidity fruits in our sample setup. In agreement with our data, other authors also found that L. monocytogenes grew on coconut slices packed under air and under modified atmosphere (Sinigaglia et al., 2006b). Growth of L. monocytogenes on cut cantaloupe or cantaloupe pulp has also been demonstrated before (Ukuku and Fett, 2002; Penteado and Leitão, 2004; Martinez et al., 2016; Nyarko et al., 2016).

Neither fruit mix 1 or fruit mix 3 permitted growth of L. monocytogenes under the tested conditions. Interestingly, individual components of these fruit mixtures by themselves have been shown to permit growth of L. monocytogenes (or L. innocua as a surrogate), such as sliced apples
(Alegre et al., 2010) and cantaloupes (Ukuku and Fett, 2002; Penteado and Leitão, 2004; Nyarko et al., 2016) (and this study), while pineapples have proven unsuitable to support the growth of $L$. monocytogenes (Penteado et al., 2014), and compounds in grapefruit and pomegranade possess antimicrobial activity (Cvetnić and Vladimir-Knezević, 2004; Hayrapetyan et al., 2012). Fruit mix 2 did not allow significant growth of L. monocytogenes under condition 1 , while under the abusive storage condition 2 there was growth potential that exceeded $1 \log$ CFU. This is despite the fact that both fruit mix 2 and 3 contained pieces of cantaloupe with a mean $\mathrm{pH}$ of 5.4. Mixing of different fruits affects the overall $\mathrm{pH}$, combines their individual microbiota and creates a new environment that has to be carefully evaluated in terms of its suitability for microbial growth. To conclusively assess the growth potential of L. monocytogenes in RTE fresh fruit mixtures, our data suggests that it is crucial to perform individual challenge tests for each new product. Since $\mathrm{pH}$ and time were significant predictors of the growth potential, particular diligence is advisable for products with longer shelf life and if the product $\mathrm{pH}$ exceeds 4.0 .

\section{References}

Alegre I, Abadias M, Anguera M, Oliveira M, Viñas I, 2010. Factors affecting growth of foodborne pathogens on minimally processed apples. Food Microbiol 27:70-6.

Angelo KM, Conrad AR, Saupe A, Dragoo H, West N, Sorenson A, Barnes A, Doyle M, Beal J, Jackson KA, Stroika S, Tarr C, Kucerova Z, Lance S, Gould LH, Wise M, Jackson BR, 2017. Multistate outbreak of Listeria monocytogenes infections linked to whole apples used in commercially produced, prepackaged caramel apples: United States, 2014-2015. Epidemiol Infect 145:848-56.

Babic I, Nguyen-the C, Amiot MJ, Aubert S, 2008 Antimicrobial activity of shredded carrot extracts on food-borne bacteria and yeast. J Appl Bacteriol 76:13541.

Bassett J, McClure P, 2008. A risk assessment approach for fresh fruits. J Appl Microbiol 104:925-43.

Beatty ME, LaPorte TN, Phan Q, Van Duyne SV, Braden C, 2004. A multistate outbreak of Salmonella enterica serotype Saintpaul infections linked to mango consumption: a recurrent theme. Clin Infect Dis 38:1337-8.

Beaufort A, Bergis H, Lardeux AL,
Lombard B, 2014. EURL Lm TECHNICAL GUIDANCE DOCUMENT for conducting shelf-life studies on Listeria monocytogenes in ready-to-eat foods. Appl Environ Microbiol 74:594-604.

Beuchat LR, Brackett RE, 1990. Inhibitory Effects of Raw Carrots on Listeria monocytogenes. Appl Environ Microbiol 56:1734-42.

Chan YC, Wiedmann M, 2009. Physiology and genetics of Listeria monocytogenes survival and growth at cold temperatures. Crit Rev Food Sci Nutr 49:23753.

Chen Y, Burall LS, Luo Y, Timme R, Melka D, Muruvanda T, Payne J, Wang C, Kastanis G, Maounounen-Laasri A, De Jesus AJ, Curry PE, Stones R, K'Aluoch O, Liu E, Salter M, Hammack TS, Evans PS, Parish M, Allard MW, Datta A, Strain EA, Brown EW, 2016. Listeria monocytogenes in Stone Fruits Linked to a Multistate Outbreak: Enumeration of Cells and Whole-Genome Sequencing. Appl Environ Microbiol 82:7030-40.

Codex Alimentarius (Adopted in 2007; Annexes II and III adopted in 2009) Guidelines on the application of general principles of food hygiene to the control of Listeria monocytogenes in ready-toeat foods. CAC/GL 61 - 2007.

Cvetnić Z, Vladimir-Knezević S, 2004. Antimicrobial activity of grapefruit seed and pulp ethanolic extract. Acta Pharm 54:243-50.

European Food Safety Authority, European Centre for Disease Prevention and Control, 2017. The European Union summary report on trends and sources of zoonoses, zoonotic agents and foodborne outbreaks in 2016. EFSA Journal $15: 148$

FDA, 2014. Environmental Assessment: Factors Potentially Contributing to the Contamination of Fresh Whole Cantaloupe Implicated in a Multi-State Outbreak of Salmonellosis. Available from: http//wayback.archive-it.orghttpswww.fda.govFoodRecallsOutbreaksE mergenciesOutbreaksucm.htm.

Feng K, Hu W, Jiang A, Xu Y, Sarengaowa, Li X, Bai X, 2015. Growth Potential of Listeria monocytogenes and Staphylococcus Aureus on Fresh-Cut Tropical Fruits. J Food Sci 80:M254854.

Hall AJ, Eisenbart VG, Etingüe AL, Gould LH, Lopman BA, Parashar UD, 2012. Epidemiology of foodborne norovirus outbreaks, United States, 2001-2008. Emerg Infect Dis 18:1566-73.

Harris LJ, Farber JN, Beuchat LR, 2003. Outbreaks Associated with Fresh 
Produce: Incidence, Growth, and Survival of Pathogens in Fresh and Fresh-Cut Produce. Compr Rev Food Sci Food Safety 2:78-141.

Hayrapetyan H, Hazeleger WC, Beumer RR, 2012. Inhibition of Listeria monocytogenes by pomegranate (Punica granatum) peel extract in meat paté at different temperatures. Food Control 23:66.72.

James C, Onarinde BA, James SJ, 2016. The Use and Performance of Household Refrigerators: A Review. Compr Rev Food Sci Food Safety 16:160-79.

Jouhara H, Nannou T, Ghazal H, 2017. Temperature and energy performance of open refrigerated display cabinets using heat pipe shelves. Energy Procedia 123:273-80.

Martinez MR, Osborne J, Jayeola VO, Katic V, Kathariou S, 2016. Capacity of Listeria monocytogenes Strains from the 2011 Cantaloupe Outbreak to Adhere, Survive, and Grow on Cantaloupe. J Food Prot 79:757-63.

McCollum JT, Cronquist AB, Silk BJ, Jackson KA, O'Connor KA, Cosgrove S, Gossack JP, Parachini SS, Jain NS, Ettestad P, Ibraheem M, Cantu V, Joshi M, DuVernoy T, Fogg NW Jr, Gorny JR, Mogen KM, Spires C, Teitell P, Joseph LA, Tarr CL, Imanishi M, Neil KP, Tauxe RV, Mahon BE, 2013. Multistate outbreak of listeriosis associated with cantaloupe. N Engl J Med 369:944-53.

Nyarko E, Kniel KE, Reynnells R, et al (2016) Survival and Growth of Listeria monocytogenes on Fresh-Cut "Athena" and "Rocky Ford" Cantaloupes During Storage at $4^{\circ} \mathrm{C}$ and $10^{\circ} \mathrm{C}$. Foodborne Pathogens Dis 13:587-91.

Penteado AL, de Castro MFPM, Rezende ACB, 2014. Salmonella enterica serovar Enteritidis and Listeria mono- cytogenes in mango (Mangifera indicaL.) pulp: growth, survival and cross-contamination. J Sci Food Agricult 94:2746-51.

Penteado AL, Leitão MFF, 2004. Growth of Listeria monocytogenes in melon, watermelon and papaya pulps. Int $\mathrm{J}$ Food Microbiol 92:89-94.

Rangel-Vargas E, Luna-Rojo AM, CadenaRamírez A, Torres-Vitela R, GómezAldapa CA, Villarruel-López A, TéllezJurado A, Villagómez-Ibarra JR, Reynoso-Camacho R, Castro-Rosas J, 2018. Behavior of 11 Foodborne Bacteria on Whole and Cut Mangoes var. Ataulfo and Kent and Antibacterial Activities of Hibiscus sabdariffa Extracts and Chemical Sanitizers Directly onto Mangoes Contaminated with Foodborne Bacteria. J Food Prot 81:743-53.

RStudio Team RStudio, 2015. RStudio: Integrated Development for R. Available from: http://www.rstudio.com/. Accessed 8 Nov 2017

Sharapov UM, Wendel AM, Davis JP, Keene WE, Farrar J, Sodha S, HyytiaTrees E, Leeper M, Gerner-Smidt P, Griffin PM, Braden C; OUTBREAK INVESTIGATION TEAM, 2016. Multistate Outbreak of Escherichia coli O157:H7 Infections Associated with Consumption of Fresh Spinach: United States, 2006. J Food Prot 79:2024-30.

Sinigaglia M, Bevilacqua A, Campaniello D, D'Amato D, Corbo MR, 2006. Growth of Listeria monocytogenes in Fresh-Cut Coconut as Affected by Storage Conditions and Inoculum Size. J Food Prot 69:820-5.

Sivapalasingam S, Barrett E, Kimura A, Van Duyne S, De Witt W, Ying M, Frisch A, Phan Q, Gould E, Shillam P, Reddy V, Cooper T, Hoekstra M,
Higgins C, Sanders JP, Tauxe RV, Slutsker L, 2003. A multistate outbreak of Salmonella enterica Serotype Newport infection linked to mango consumption: impact of water-dip disinfestation technology. Clin Infect Dis 37:1585-90.

Smith JL, Liu Y, Paoli GC, 2013. How does Listeria monocytogenes combat acid conditions? Can J Microbiol 59:141-52.

Ukuku DO, Fett W, 2002. Behavior of Listeria monocytogenes Inoculated on Cantaloupe Surfaces and Efficacy of Washing Treatments to Reduce Transfer from Rind to Fresh-Cut Pieces. J Food Prot 65:924-30.

Vestrheim DF, Lange H, Nygård K, Borgen K, Wester AL, Kvarme ML, Vold L, 2016. Are ready-to-eat salads ready to eat? An outbreak of Salmonella Coeln linked to imported, mixed, pre-washed and bagged salad, Norway, November 2013. Epidemiol Infect 144:1756-60.

Wickham H, 2009. ggplot2: elegant graphics for data analysis. In: ggplot2: elegant graphics for data analysis. Springer, New York,

Willis C, McLauchlin J, Amar C, SadlerReeves L, Elviss N, Aird H, Fox A, Kaye M, 2016. Assessment of the Microbiological Safety of Precut Fruit from Retail and Catering Premises in the United Kingdom. J Food Prot 79:598-604.

Ziegler M, Jang H, Gopinath G, Horlbog JA, Stephan R, Guldimann C, 2018. Whole-Genome Shotgun Sequencing of Three Listeria monocytogenes Strains Isolated from a Ready-to-Eat SaladProducing Facility in Switzerland. Genome Announc 6:1975. 